doi: 10.25005/2074-0581-2020-22-4-650-654

\title{
EXTREMELY RARE CASE OF BILATERAL EXOGENIC RHINOLITHIASIS WITH 16 YEARS HISTORY
}

\author{
U.A. KURBANOV ${ }^{1,2}$, S.M. DZHANOBILOVA ${ }^{1}$, SH.I. KHOLOV ${ }^{1,3}$, K.M. MARDONZODA ${ }^{1,4}$
}

${ }^{1}$ Khatlon State Medical University, Dangara, Republic of Tajikistan

2 Department of Surgical Diseases № 2 named after Academician N.U. Usmanov, Avicenna Tajik State Medical University, Dushanbe, Republic of Tajikistan

3 Republican Scientific Center for Cardiovascular Surgery, Dushanbe, Republic of Tajikistan

4 Republican Clinical Hospital of Dangara, Dangara, Republic of Tajikistan

The article describes a rare case of bilateral rhinolithiasis. The presence of a foreign body in the nasal cavity comprised 16 years. Pathogenetic aspects of the occurrence of the rhinoliths and their chemical composition are presented. Frequent recurrent acute exacerbations of chronic rhinitis, sensations of unpleasant smell, partial loss of smell, breathing problems due to nasal congestion and durable ineffectiveness of previous treatment triggered the patient to address to the clinic. $\mathrm{CT}$ revealed the presence of a foreign body on both sides of the nasal cavity. The patient underwent the surgery on bilateral rhinolithiasis with the application of precision technology and optical zoom. The nidus of rhinolith became plastic bullets of a toy gun. Intraoperative complications were not observed. The duration of hospitalization was 5 days. Follow-up evaluation by CT of the nasal cavity and paranasal sinuses in the period of 4 months after surgery revealed the absence of foreign bodies and nasal symptoms.

Keywords: Foreign body, bilateral rhinolithiasis, nasal cavity, CT scan.

Для цитирования: Kurbanov UA, Dzhanobilova SM, Kholov Shl, Mardonzoda KM. Extremely rare case of bilateral exogenic rhinolithiasis with 16 years history. Vestnik Avitsenny [Avicenna Bulletin]. 2020;22(4):650-4. Available from: https://doi.org/10.25005/2074-0581-2020-22-4-650-654

\section{КРАЙНЕ РЕДКИЙ СДУЧАЙ ДВУХСТОРОННЕГО ЭКЗОГЕННОГО РИНОЯИТА 16 ЛЕТНЕЙ ДАВНОСТИ}

\author{
У.А. КУРБАНОВ ${ }^{1,2}$, С.М. ДЖАНОБИЛОВА ${ }^{1}$, Ш.И. ХО ДОВ $^{1,3}$, К.М. МАРДОНЗОДА
}

1 Хатлонский государственный медицинский университет, Дангара, Республика Таджикистан

2 Кафедра хирургических болезней № 2 им. акад. Н.У. Усманова, Таджикский государственный медицинский университет им. Абуали ибни Сино,

Душанбе, Республика Таджикистан

3 Республиканский научный центр сердечно-сосудистой хирургии, Душанбе, Республика Таджикистан

4 Дангаринская республиканская клиническая больница, Дангара, Республика Таджикистан

Ключевые слова: инородное тело, двухсторонний ринолит, полость носа, компьютерная томография.

For citation: Kurbanov UA, Dzhanobilova SM, Kholov Shl, Mardonzoda KM. Extremely rare case of bilateral exogenic rhinolithiasis with 16 years history. Vestnik Avitsenny [Avicenna Bulletin]. 2020;22(4):650-4. Available from: https://doi.org/10.25005/2074-0581-2020-22-4-650-654

\section{INTRODUCTION}

The foreign body (corpora aliena) of the nasal cavity can be found frequently, especially in the practice of pediatric otorhinolaryngologist, but rhinoliths are always a rare finding, while occurrence of bilateral rhinoliths is a very rare episode [1].

Rhinolith (rhinolithus: rhino - nose + lithos - stone) mineralized mass, that results from the deposition of phosphoric acid and carbonate salt of calcium and mucus on the surface of a foreign body which localizes in the nasal cavity for a long period of time [2].

Rhinolith is mainly detected unilaterally [3]. In the most cases, rhinolith is located in the lower nasal meatus. Predominantly (78\%), rhinoliths embedded in the posterior part of the nasal cavity and less often (22\%) - in the anterior part [4]. Bilateral rhinolithiasis can be found very rarely, there are only 5 cases described in the literature $[1,5]$.

Durable existence of a foreign body within the intranasal structures may follow by the formation of rhinolith which causes structural changes such as nasal septum deviation, hypotrophy of the lower nasal concha and displacement of the bone part of the nasal septum base $[6,7]$.

The symptoms of rhinolith are non-specific $[8,9]$. They usually cause prolonged unilateral or bilateral congested nasal passages and nasal discharges of a mucopurulent character. In the case of a long presence of a foreign body in the nasal cavity, there is a possibility of inflammatory diseases in paranasal sinuses, dystrophic and atrophic changes in the mucous membrane, perforation of the walls of the nasal cavity, nasal bleedings, neurological facial pain, orbital and intracranial complications $[2,6]$.

Every individual report of rhinolith sheds light on the pathogenesis of the disease. Considering the rarity of this pathology, we presented our own clinical observation - detection of bilateral rhinolith with existence of 16 years, and the nidus of which was the plastic bullets of a toy gun.

\section{Clinical case}

Patient K, 19 years old, addressed to the Republican Clinical Hospital of Dangara with complaints for frequent exacerbations 
of rhinitis, nasal discharges, unpleasant odors, partial loss of smell, difficulties in breathing and night snoring. From the anamnesis (according to the parents) it turned out that the child in the age of 3 , during playing a game, pushed in a foreign body in the nasal cavity which presumably was a bead or bullet of a toy gun. For this reason, the parents consulted with a doctor from local outpatient department where the foreign body was not detected. After 9 years, at the age of 12 , with complaints on a nasal stuffiness and difficulty in nasal breathing, the patient was examined again and received a long-term treatment for sinusitis. The effect of the treatment was a short-term. Lack of any improvement from the conducted medical treatment caused the patient to be consulted by a local healer who prescribed some herbs according to the recipes of traditional medicine. However, this method of treatment was an ineffective either.

External nose had a natural shape and size. Breathing difficulties and congestion were observed on both sides of the nose. The loss of smell was reported by the patient. The nasal passages were not obstructed. An unpleasant foul smelling nasal discharge came from the nose. During anterior rhinoscopy in both inferior nasal passages a round shape mass of grey-yellow color with uneven surface was detected. Visualization of the mass in the left nasal passage was relatively difficult compare to the right nasal passage due to the

Fig. 1 CT of the nasal cavity, axial section: $a, b$ - rhinolith in the left nasal passage with a core diameter of $6 \mathrm{~mm}$ in the center, at a distance of $25 \mathrm{~mm}$ from the nostrils; $c, d$-rhinolith in the right nasal passage with a core diameter of $6 \mathrm{~mm}$ in the center, at a distance of $18 \mathrm{~mm}$ from the nostrils
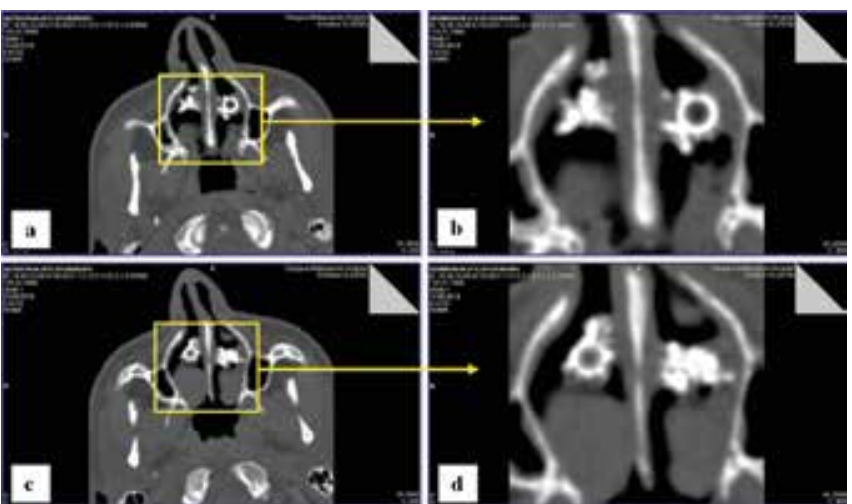

Fig. 2 CT of the nasal cavity, coronary section: $a, b$ - radiopaque formation - rhinolith, inlaid with calcification in the right nasal passage with a spherical core; $c, d$-rhinolith, inlaid with calcification in the left nasal passage with a spherical core
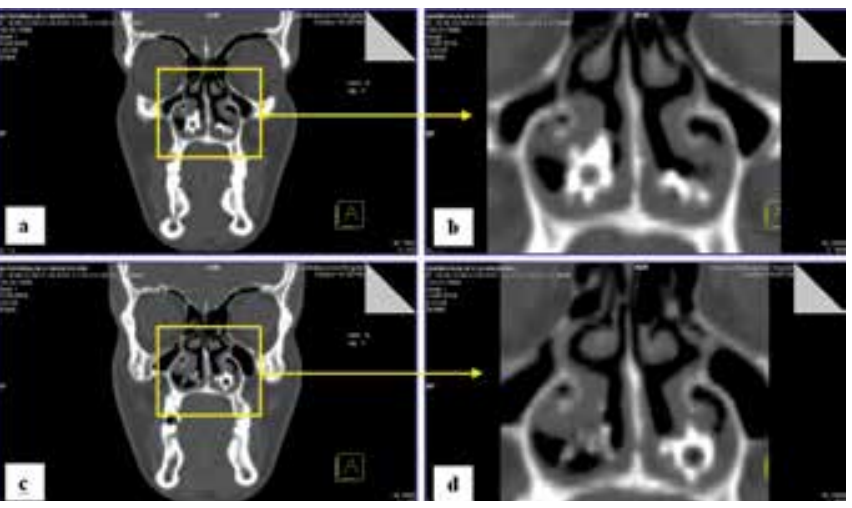

deeper localization of the mass on the left side. Nasal septum was deviated mostly to the left side with formation of the ridge adjacent to the inferior turbinate. The mucous membrane of the nasal cavity was swollen and hyperemic. Inferior turbinate hypertrophy and enlargement in the left nasal passage was detected. During posterior rhinoscopy the mucous membrane was of pink color and moist, the choanal openings and nasopharengeal vault were not obstructed.

CT of the nasal cavity and paranasal sinuses in all three projections with 3D-modeling was performed (Fig. 1-3). As a result, the radiopaque substances of spherical shape sized $6 \times 6 \mathrm{~mm}$ were detected in the lower nasal passages on both sides of the nasal cavity.

In addition, lower nasal turbinate hypertrophy along with deformation and deviation of the nasal septum to the left were observed. Thus, on the basis of an anamnesis, local examination, anterior rhinoscopy and $\mathrm{CT}$, the patient was diagnosed with "Foreign bodies of the nasal cavity - bilateral rhinolith".

After the pre-operation preparation, the patient under the general endotracheal anesthesia underwent the surgical removal of foreign bodies (rhinolith) from the nasal cavity, as well as leftside conchectomy and the resection of anterior nasal spine with closed access using precision technology and optical enlargement. Rhinolith on the right side of the nasal cavity was located in the lower nasal meatus at a distance of $18 \mathrm{~mm}$ from the nostril. The tightly fused rhinolith was hardly isolated by using a special curettage spoon and was crushed into particles and furthermore removed. The similar method was used to remove the rhinolith from the lower left nasal meatus, which was located deeper at a distance of $25 \mathrm{~mm}$ inward from the nostrils. After removal of foreign bodies, a left-sided conchectomy and resection of the deviated part of the anterior nasal spine with closed access was additionally performed. The nasal cavity was washed and tamponed with the gauze moistened in glycerin.

Fig. 3 CT of the nasal cavity, sagittal section and 3D model of nasal septum deviation in the bone part of the nasal septum: a-irregular rhinolith under the lower nasal concha in the right nasal passage; $b-$ rhinolith with a spherical nucleus in the right nasal canal; $c$ - rhinolith under the lower nasal concha in the left nasal passage; $d$-rhinolith with a spherical nucleus in the left nasal canal; $e$ - a curved septum of the nose with a pathological bone crest; $f-3 D$ model of the nasal cavity with radiopaque formations on both sides
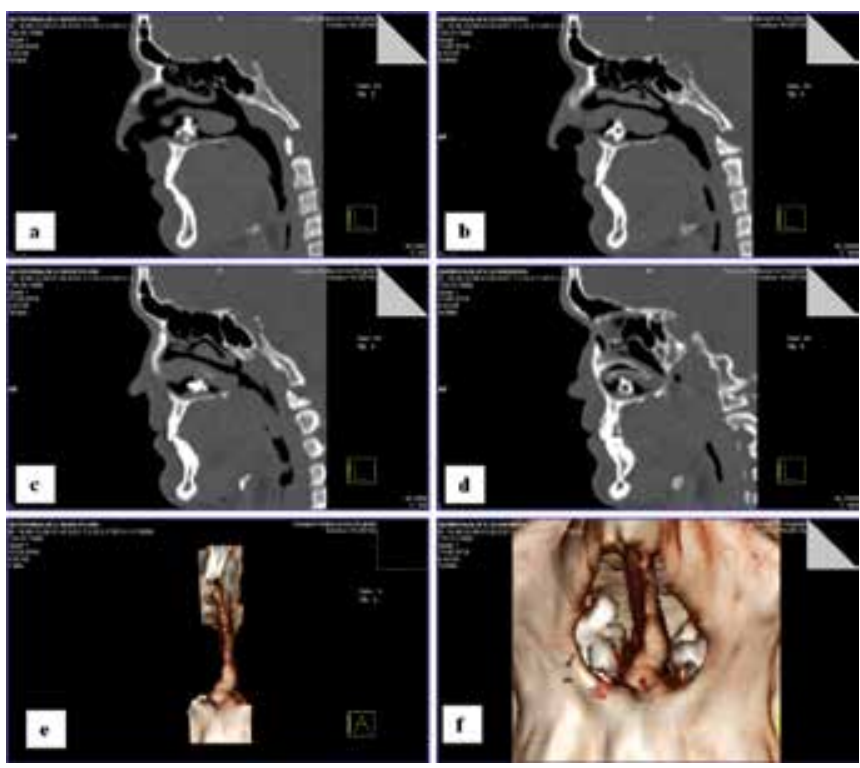

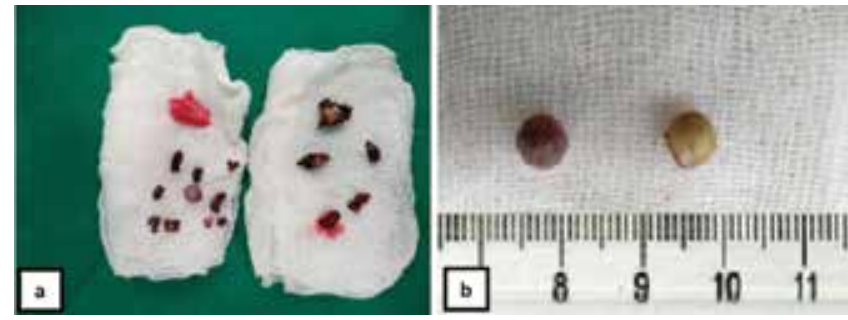

Fig. 4 Removed foreign bodies - bilateral rhinolith: a - crushed into pieces and extracted rhinolith on both sides; $b$ - peeled from calcifications of rhinolith nucleus - toy gun bullet with a diameter of $6 \mathrm{~mm}$

Fig. 5 CT of the nasal cavity in 3 projections and a 3D model of the bone part of the nasal septum in the postoperative period (4 months): $a$ - axial section - there are no traces of the presence of rhinolitis; $b$ - coronary section - nasal passages are clean, free, there is no lower nasal concha on the left; $c, d$ - sagittal sections - nasal passages are free, passable, there is no lower nasal concha on the left; $e-$ pathological bone crest is absent; $f-3 D$ model of the nasal cavity - no traces of the presence of foreign bodies are observed

Macro-preparation: removed rhinolith were cleaned from layers of inlaid mineralized nasal masses. The plastic bullets of a toy gun were the core of the rhinolith (Fig. 4).

In the postoperative period, the patient underwent comprehensive anti-inflammatory and antibacterial therapy for 5 days. The postoperative period was smooth. The patient noted the restoration of nasal breathing and the disappearance of all «nasal» complaints immediately after the removal of the packed gauze. During the monthly follow-up examination in the first three months after the operation, complaints were absent, the condition was satisfactory, positive dynamics were observed.

On the control CT of the nasal cavity performed four months later after the operation, the nasal passages were clean, free, without left lower nasal concha and any signs of foreign body presence (Fig. 5).

\section{Discussion}

The first reliably documented case report of a calcified foreign body in the nasal cavity was published by a Danish medical scientist Bartholin in 1654, when he described a foreign body encrusted with calcification and grown around a foreign body - a cherry bone. For the first time the encrusted calcifications from nasal cavity were subjected to the chemical analyzes by Axmann in 1829. In 1845, for the first time, for the description of partially or fully calcified foreign bodies of the nasal cavity was provided the term "rhinolith". Later, in 1943, Polson wrote a monograph in which he described about 384 cases of rhinolithiasis [4].

In general, rhinilith compose of calcium phosphate (44.7\%), calcium carbonate $(20.69 \%)$, magnesium phosphate (19.46\%), organic elements $(13.2 \%)$ and water $(2.5-4.95 \%)[8,10]$. The mineral composition of the studied rhinoliths is a non-stoichiometric hydroxyapatite carbonate. The structural features of apatite can be explained by the heterogeneity of the organic components secreted by the mucous membrane in the nasal passage [11].

Previously, the calcified foreign bodies in the nasal cavity were designated as "false" or "true" rhinoliths. Currently, depending
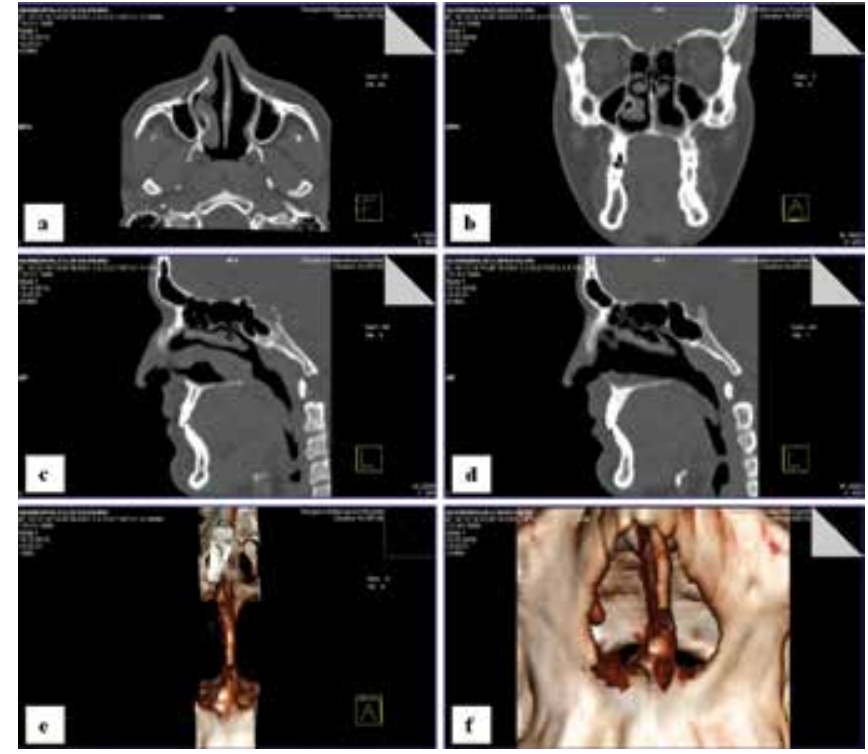

upon the type of nidus around which inlay occurs, those terms were replaced by exogenous and endogenous rhinolithiasis. Those rhinoliths formed around inorganic material which inserted inside the nasal cavity, such as fruit bones, small parts of toys, small household items, and etc, are called exogenous. Endogenous rhinoliths are those which are formed around organic materials, such as clotted blood, products of cell lysis and necrosis of the mucous membrane, ectopic teeth, bone fragments $[6,12]$.

Rhinolith in nose develop as a result of foreign body presence in early age, most often in children of 2-3 years old, when they insert into their nose small objects. Elder children can already speak and complain to their parents about getting in to their nose foreign bodies. Accordingly, parents tend to remove a foreign body or seek for a medical care. In case of detection of rhinolith with a nucleus in a patient of 25 years old, then apparently a foreign body existed in the nose until the formation of rhinolith approximately for 21-22 years $[7,13]$.

The anterior rhinoscopy, rigid endoscopy, conventional radiography and $\mathrm{CT}$ scan are applied for diagnosis purposes of rhinolithiasis and used for identification of volumetric masses. Rhinolith should be differentiated from calcified polyp, ossified fibroids, single tumor, osteoma, chondrosarcoma, chondroma and carcinoma. Thus, CT of the nose and paranasal sinuses determines the precise location and size of the rhinolith, and also reveals the concomitant pathologies of this area, which in case of necessity can be corrected in one step $[2,14]$.

\section{CONCLUSIONS}

As a result, the clinical case of bilateral rhinolithiasis demonstrated in the article is of scientific interest due to the extreme rarity of this pathology, and also proves that rhinolithiasis can be the cause of prolonged difficulty in nasal breathing, mucopurulent discharge from the nose and unpleasant odor. Due to similar complaints with other pathologies of the nose, rhinolithiasis often remains undiagnosed for a long time and is treated for years with inappropriate diagnoses - sinusitis, allergic rhinitis, etc. CT application in such cases appreciates an accurate determination of the pathology and therefore allows a correct treatment. 


\section{REFERENCES}

1. Gupta M, Singh S, Kumar D. Bilateral rhinolith: A rare cause of pansinusitis. Research. 2014;1:909. Avaliable from: https://doi: 10.13070/rs.en.1.909

2. Hadi U, Ghossaini S, Zaytoun G. Rhinolithiasis: A forgotten entity. Otolaryngol Head Neck Surg. 2002;126(1):48-51.

3. Patil K, Guledgud MV, Malleshi SN. Rhinolith. Indian Journal of Dental Research. 2009;20(1)114-6.

4. Polson CJ. "On rhinoliths," Journal of Laryngology \& Otology. 1943;58(3):79116.

5. Genc S, Kahraman E, Ozel H, Genc M. Bilateral rhinolithiasis. Journa Craniofacial Surgery. 2011;22(6):24-9. Avaliable from: https://doi:10.1097/ SCS.0b013e318231e352

6. Kharlantseva AV, Chernov Al, Kuydin IYu, Stukalina LV, Martynov SA, Khirnetkina AF. Redkiy sluchay rinolita u vzroslogo patsienta [Rare case of rhinolith in an adult patient]. Sibirskiy meditsinskiy zhurnal. 2010;1:124-6.

7. Musatenko LYu, Zenger VG, Mustafaev DM, Epanchintseva AS, Kopchenko OO. Bessimptomnoe nakhozhdenie rinolita v polosti nosa [The asymptomatic presence of rhinolith in the nasal cavity]. Rossiyskaya otorinolaringologiya. 2007;4:48-50.

8. Bobrov VM. Klassifikatsiya i klinicheskie nablyudeniya rinolitov u vzroslykh [Classification and clinical observation of rhinoliths in adults]. Vestnik otorinolaringologii. 2012;5:88-90.
9. Kharoubi S. Rhinolithiasis associated with septal perforation: A case report. Acta Oto-Rhino-Lalyngologica Belgica. 1998;52(3):241-5.

10. Bobrov VM. Klassifikatsiya rinolitov [Classification of rhinoliths]. Vestnik otorinolaringologii. 1998;6:41-3.

11. Katkova VI, Filippov VN. Rinolity: biomineralogicheskie aspekty [Rhinoliths: biomineralogical aspects]. Vestnik Instituta geologii Komi NC UrO RAN. 2015;10:35-7. Available from: https://doi:10.19110/2221-1381-2015-10-3537

12. Shaw LC-K. Rhinolith of endogenous origin: A rare entity. Surgical Practice. 2007;11(1):48-50. Avaliable from: https://doi:10.1111/j.17441633.2007.00329.x

13. Bobrov VM, Korobeynikova NM, Malysheva LA. Tri nablyudeniya rinolita [Three observations of rhinolithiasis]. Vestnik otorinolaringologii. 2007;1:49 50.

14. Atmaca S, Belet N, Sensoy G, Belet U. Rhinolithiasis: An unusual cause of sinusitis complicated with frontal osteomyelitis and epidural abscess. The Turkish Journal of Pediatrics. 2010;52:187-90.

\section{(i) author information}

Kurbanov Ubaydullo Abdulloevich, Corresponding Member of the National Academy of Sciences, Doctor of Medical Sciences, Full Professor, Rector of Khatlon State Medical University; Professor of the Department of Surgical Diseases № 2 named after Academician N.U. Usmanov, Avicenna Tajik State Medical University

Researcher ID: E-1476-2019

ORCID ID: 0000-0002-5546-7180

Author ID: 845057

SPIN: 5959-8681

E-mail: kurbonovua@mail.ru

Dzhanobilova Sitora Murodilloevna, Candidate of Medical Sciences, Researcher, Science Innovation Department, Khatlon State Medical University Researcher ID: E-1438-2019

ORCID ID: 0000-0001-9458-1798

E-mail: sattarstar77@gmail.com

Kholov Sharafdzhon Iskhokdzhonovich, Surgeon, Department of Reconstructive and Plastic Microsurgery, Republican Scientific Center for Cardiovascular Surgery; Assistant, Department of Surgical Disciplines № 1, Khatlon State Medical University

Researcher ID: E-1387-2019

ORCID ID: 0000-0003-1437-7979

E-mail: microsurgerytj@gmail.com

Mardonzoda Kurbonalii Mirzo, Surgeon, Republican Clinical Hospital of Dangara; Assistant, Department of Surgical Disciplines № 1, Khatlon State Medical University

Researcher ID: E-1383-2019

ORCID ID: 0000-0001-9507-9089

E-mail: tibplus@gmail.com

Information about the source of support in the form of grants, equipment, and drugs

The authors did not receive financial support from manufacturers of medicines and medical equipment

Conflicts of interest: The authors have no conflicts of interest

\section{СВЕДЕНИЯ ОБ АВТОРАХ}

Курбанов Убайдулло Абдуллоевич, член-корр. Национальной академии наук, доктор медицинских наук, профессор, ректор Хатлонского государственного медицинского университета; профессор кафедры хирургических болезней № 2 им. акад. Н.У. Усманова, Таджикский государственный медицинский университет им. Абуали ибни Сино

Researcher ID: E-1476-2019

ORCID ID: 0000-0002-5546-7180

Author ID: 845057

SPIN-код: 5959-8681

E-mail: kurbonovua@mail.ru

Джанобилова Ситора Муродиллоевна, кандидат медицинских наук, научный сотрудник отдела науки и инноваций, Хатлонский государственный медицинский университет

Researcher ID: E-1438-2019

ORCID ID: 0000-0001-9458-1798

E-mail: sattarstar77@gmail.com

Холов Шарафджон Исхокджонович, врач-хирург отделения реконструктивной и пластической микрохирургии, Республиканский научный центр сердечно-сосудистой хирургии; ассистент кафедры хирургических дисциплин № 1, Хатлонский государственный медицинский университет Researcher ID: E-1387-2019

ORCID ID: 0000-0003-1437-7979

E-mail: microsurgerytj@gmail.com

Мардонзода Курбоналии Мирзо, ассистент кафедры хирургических дисциплин № 1, Хатлонский государственный медицинский университет; врач-хирург Дангаринской республиканской клинической больницы Researcher ID: E-1383-2019

ORCID ID: 0000-0001-9507-9089

E-mail: tibplus@gmail.com

Информация об источнике поддержки в виде грантов, оборудования, лекарственных препаратов

Финансовой поддержки со стороны компаний-производителей лекарственных препаратов и медицинского оборудования авторы не получали 


\section{ADDRESS FOR CORRESPONDENCE:}

\section{Kholov Sharafdzhon Iskhokdzhonovich}

Surgeon, Department of Reconstructive and Plastic Microsurgery, Republican Scientific Center for Cardiovascular Surgery; Assistant, Department of Surgical Disciplines № 1, Khatlon State Medical University

734003, Republic of Tajikistan, Dushanbe, Sanoi str., 33 Tel.: +992 (918) 890079

E-mail: microsurgerytj@gmail.com

\section{AUTHOR CONTRIBUTIONS}

Conception and design: KUA, DSM

Data collection: KhShl, MKM

Analysis and interpretation: KUA, KhShl, MKM

Writing the article: DSM, KhShl

Critical revision of the article: KUA, KhShl

Overall responsibility: KUA

This case study was previously published in the journal "Simurg" in Russian (Kurbanov UA, Dzhanobilova SM, Kholov Shl, Makhmudov IKh, Mardonzoda RM. Krayne redkiy sluchay dvukhstoronnego ekzogennogo rinolita shestnadtsatiletney davnosti (klinicheskoe nablyudenie). Simurg. 2019;3:1421.). Given the extremely rare case presented, as well as the agreement between the chief editors of the journals "Simurg" and "Avicenna Bulletin" in the framework of the COPE recommendations, this case report is reprinted in English with some changes and additions

\section{АДРЕС ДЛЯ КОРРЕСПОНДЕНЦИИ:}

\section{Холов Шарафджон Исхокджонович}

врач-хирург отделения реконструктивной и пластической микрохирургии, Республиканский научный центр сердечно-сосудистой хирургии; ассистент кафедры хирургических дисциплин № 1, Хатлонский государственный медицинский университет

734003, Республика Таджикистан, г. Душанбе, ул. Санои, 33 Тел.: +992 (918) 890079

E-mail: microsurgerytj@gmail.com

\section{ВКЛАД АВТОРОВ}

Разработка концепции и дизайна исследования: КУА, ДСМ

Сбор материала: ХШИ, МКМ

Анализ полученных данных: КУА, ХШИ, МКМ

Подготовка текста: ДСМ, ХШИ

Редактирование: КУА, ХШИ

Общая ответственность: КУА

Статья, посвящённая описанию крайне редкого случая двухстороннего ринолита, ранее была опубликована в журнале "Симург» на русском языке (Курбанов УА, Джанобилова СМ, Холов Ши, Махмудов ИХ, Мардонзода КМ. Крайне редкий случай двухстороннего экзогенного ринолита шестнадиатилетней давности (клиническое наблюдение). Симург. 2019;3:14-21.). Учитывая редкость патологии, а также договорённость между главными редакторами журналов "Симург» и "Вестник Авиценны» в рамках рекомендаций СОРЕ, настоящая статья с некоторыми изменениями и дополнениями печатается повторно на английском языке

$\begin{array}{ll}\text { Поступила } & 13.10 .2020 \\ \text { Принята в печать } & 28.12 .2020\end{array}$

Submitted $\quad 13.10 .2020$

Accepted $\quad 28.12 .2020$ 